MagdalenA BARAŃSKA

ORCID ID 0000-0003-3615-1321

KONRAD NOWAK-KLUCZYŃSKI

ORCID ID 0000-0002-7814-1650

Uniwersytet im. Adama Mickiewicza

$w$ Poznaniu

\title{
EPIZODYSTA NAUKOWY \\ - O PRACY NAUCZYCIELA AKADEMICKIEGO. MIĘDZY DYDAKTYKĄ A NAUKĄ
}

\begin{abstract}
Aвstract. Barańska Magdalena, Nowak-Kluczyński Konrad, Epizodysta naukowy - o pracy nauczyciela akademickiego. Między dydaktyka a nauka [Scientific Episodist - About the Work of an Academic Teacher. Between Didactics and Science]. Studia Edukacyjne nr 53, 2019, Poznań 2019, pp. 161-185. Adam Mickiewicz University Press. ISSN 1233-6688. DOI: 10.14746/se.2019.53.10
\end{abstract}

Work at the university is a special type of professional activity. Being an academic teacher is a very interesting, responsible and complex profession, but there is room for tasks, duties and roles between didactics and science which is not included in any definition. In the sheer volume of teaching, administrative and logistical duties, research is coming to the fore.

Key words: academic teacher, lecturer, scientist, academic, educator, scientific episodist, university, professional activity

Nauczyciel to rodzaj niewolnika, który wiecznie nie ma czasu Lucy Maud Montgomery ${ }^{1}$

\section{Zamiast wstępu}

Praca na uczelni wyższej to szczególny rodzaj aktywności zawodowej. Specyfika pracy nauczyciela akademickiego nie daje ująć się w sztywne ramy i opisy, przez co pewne jej aspekty wymykają się definicjom i charakterysty-

\footnotetext{
${ }^{1}$ Lucy Maud Montgomery, Ania z Szumiacych Topoli, Warszawa 1998.
} 
kom. Między dydaktykiem a naukowcem istnieje ogromna przestrzeń, którą wypełniają nie tylko oczekiwania samych akademików, ale studentów, pracodawców, społeczeństwa, jak również, a może przede wszystkim, ich cele, obowiązki, potrzeby, obawy i problemy. Praca nauczyciela akademickiego nie jest tak oczywista jakby się wydawało. Dokonując opisu tej profesji, a tym samym osób ją realizujących, należy uwzględnić jej ewolucję na przestrzeni ostatniego ćwierćwiecza - odnoszącą się do zakresu czynności, obowiązków, cech osobowych i kompetencji. Współcześnie potocznie nazywany wykładowca, to w praktyce nie tylko naukowiec - badacz i dydaktyk - organizator, kierownik i kontroler procesu dydaktycznego, ale i „księgowy”, sprawozdawca, mentor, opiekun studentów (roku, specjalności, koła naukowego), sędzia, tutor, negocjator, przewodnik, archiwista - kolekcjoner, a nawet terapeuta i wychowawca. Niniejszy artykuł dotyka kwestii polisemantyczności profesji nauczyciela akademickiego i wielozadaniowości wpisanej w jego naturę.

\section{Uniwersytet $\mathrm{i}$ jego charakter $\mathrm{w}$ perspektywie historycznej}

Świadectwem doniosłości uniwersytetów stały się definicje charakteryzujące uniwersytet jako

najstarszy, a zarazem podstawowy typ europejskiej wielowydziałowej wyższej uczelni mającej prawo nadawania stopni naukowych i łączącej funkcje dydaktyczne (kształcenie najwyżej kwalifikowanej kadry zawodowej i pracowników nauki) z funkcjami naukowymi (prowadzenie prac badawczych)².

Definicja o tyle trafna, iż identyczne takie jej sformułowania można znaleźć w literaturze przedmiotu, leksykonach pedagogicznych ${ }^{3}$, czy powszechnej encyklopedii ${ }^{4}$. W Encyklopedii pedagogicznej XXI wieku uniwersy tet definiuje się jako

najstarszy rodzaj szkoły wyższej, której celem jest prowadzenie badań naukowych, kształcenie wykwalifikowanych pracowników oraz przygotowanie kadr naukowych. Uniwersytet, pojmowany jako „universitas”, jest wszechnicą ludzi i nauki, jego siły dzięki której istnieje od kilku wieków wielkość reprezentowanych w nim nauk oraz jedność badań i nauczania ${ }^{5}$.

2 B. Milerski, B. Śliwerski (red.), Pedagogika. Leksykon PWN, Warszawa 2000, s. 254-255.

${ }^{3}$ Zob. W. Okoń, Nowy stownik pedagogiczny, Warszawa 2007, s. 442; B. Milerski, B. Śliwerski (red.), Leksykon-Pedagogika, Warszawa 2000, s. 253-254.

${ }_{4}$ Zob. Encyklopedia Powszechna PWN, Warszawa 2005.

${ }^{5}$ T. Bauman, Uniwersytet, [w:] Encyklopedia pedagogiczna XXI wieku, t. VI, red. T. Pilch, Warszawa 2007, s. 973. 
W Stowniku pedagogicznym znajdujemy niemalże identyczną definicję uniwersytetu z jedną różnicą w opisie dotyczącą jego „nietechnicznego charakteru”' . Jednakże, jak podkreśla Tadeusz Lewowicki, nazwa uniwersytetu nabrała współczesnego znaczenia nie od razu. Uniwersytet jako wielowydziałowa uczelnia był "studium generale" i to określenie odnoszono do instytucji, w której można było zdobywać wiedzę z różnych nauk czy dziedzin wiedzy. W ramach „studium generale" funkcjonowały - w ówczesnym pojęciu - różne uniwersytety. Dopiero z biegiem lat nazwą „uniwersytet” objęto całość wydziałów, szkół, uniwersytetó $\mathrm{w}^{7}$. Uniwersytet jako instytucja spełnia wielorakie funkcje $\mathrm{w}$ społeczeństwie ${ }^{8}$. Niezmiennymi celami od dawien dawna szkół wyższych są: działalność wychowawczo-dydaktyczna oraz działalność naukowo-badawcza9 ${ }^{9}$.

Idea europejskiej szkoły wyższej uniwersyteckiej miała początki w starożytności. W 387 roku p.n.e. Platon ${ }^{10}$ założył w ogrodach ateńskich Akademię, która w sposób zorganizowany miała wychowywać i kształcić władców syrakuzańskich na mężów stanu ${ }^{11}$. Przetrwała ona do 529 roku, a więc istniała aż 916 lat $^{12}$. Już w czasach nowożytnych, w II wieku n.e., utworzono rzymskie Ateneum cesarza Hadriana oraz uniwersytet w Aleksandrii. Na przełomie III i IV wieku n.e. zaczęły powstawać szkoły retorów, które stanowiły następnie podstawę szkół wyższych kształcących prawników w Imperium Rzymskim. Wspólną cechą tych szkół była forma dobrowolnego zrzeszania się wokół obranego autorytetu osób chcących zdobyć wiedzę. Natomiast, typ wielowydziałowej, znanej współcześnie, szkoły wyższej, kształcącej wysoko kwalifikowanych absolwentów, prowadzącej działalność badawczą oraz uprawnionej do nadawania stopni naukowych, rozwinął się dopiero w średniowiecznej Europie Zachodniej (Włoszech, Francji i Anglii) w XI-XII wieku. Kolejne dwa stulecia obejmowały fazę upowszechniania uniwersytetu w krajach zachodnio- i północnoeuropejskich, a na przełomie XIX i XX wieku instytucje kształcące $\mathrm{w}$ zakresie nauk humanistycznych i matematyczno-przyrodniczych oraz rozwijające badania naukowe $w$ tych dziedzinach istniały już w całej Europie ${ }^{13}$.

${ }^{6}$ Cz. Kupisiewicz, M. Kupisiewicz, Stownik pedagogiczny, Warszawa 2009, s. 185-186.

7 T. Lewowicki, Kształcenie uniwersyteckie - siła tradycji, presja wspótczesności, pytania o przyszłość, przesłania, [w:] Uniwersytet. Społeczeństwo. Edukacja, red. W. Ambrozik, K. Przyszczypkowski, Poznań 2004, s. 45.

${ }^{8}$ Zob. S. Kot, Historia wychowania. Od starożytnej Grecji do połowy XVIII wieku, Warszawa 1996, s. 156-166.

9 T. Alek-Kowalski, Nauka. Wielkopolska. Uczeni. Szkice socjologiczne, Poznań 2003, s. 73.

${ }^{10}$ Zob. F.W. Araszkiewicz, Wybór materiatów z historii wychowania i myśli pedagogicznej, Poznań 1974, s. 12-16.

${ }^{11}$ M. Krajewski, Dzieje wychowania i doktryn pedagogicznych, Płock 2005, s. 293.

${ }^{12}$ H. Markiewiczowa, Wybrane zagadnienia z historii wychowania, Warszawa 2001, s. 17.

${ }^{13}$ M. Cylkowska-Nowak, Uniwersytet - europejskie tradycje ksztatcenia wyższego, [w:] Encyklopedia pedagogiczna XXI wieku, t. VI, s. 979. 
O doniosłej roli uniwersytetów świadczy fakt, iż samo ich powstanie w średniowiecznej epoce nie tylko było przełomem umysłowym, ale również rozkwitem intelektualnej kultury ${ }^{14}$. Uniwersytet był jednym z największych osiągnięć kultury duchowej średniowiecza ${ }^{15}$. Jacques Le Goff definiuje średniowieczny uniwersytet jako „korporację grupującą wszystkich (universitas) profesorów i studentów w danym mieście" ${ }^{16}$. Uniwersytety w ciągu dziewięciu wieków swego istnienia wywierały ogromny wpływ na rozwój nauk, a także stały się jednym z głównych czynników instytucjonalizacji i profesjonalizacji poszczególnych jej dyscyplin ${ }^{17}$. Od wieków są one chlubą narodów, które dbają o naukę i to w niej upatrują szanse na sukcesy w różnych dziedzinach życia ${ }^{18}$. Jak pisał Jan Baszkiewicz:

Znany jest powszechnie pogląd ludzi średniowiecza, że dwie władze rządzą światem: duchowna i świecka. Jednakże w XIII wieku upowszechniał się w kręgach elity intelektualnej pogląd, że nie dwie, lecz trzy władze rządzą światem: autorytet władzy duchownej, siła doczesna monarchii, wreszcie potęga nauki, której symbolem jest uniwersytet ${ }^{19}$.

${ }^{14}$ Nowy typ szkoły, jaką stał się uniwersytet, powstał na kanwie zapotrzebowania edukacyjnego młodzieży duchownej i świeckiej już w XII wieku. Pojawienie się uniwersytetów w ówczesnej Europie było nieodzownie powiązane z rozwojem aglomeracji miejskiej. Uniwersytet stał się korporacją, cechem, stowarzyszeniem danej grupy ludzi. Od początku swego istnienia uniwersytety miały trzy podstawowe przywileje: autonomię, monopol nadawania stopni naukowych oraz prawo do strajku. Rozkwit uniwersytetów przypada na wiek XIII. Jest to okres ewolucji pisma, unowocześniania techniki wydawniczej książek, a także rozwoju scholastyki, jako nowej metody myślenia. Do dziś dnia trudno o precyzyjne określenie, który $\mathrm{z}$ uniwersytetów był najstarszy. Umownie przyjmuje się, iż najstarszym uniwersytetem, który powstał jako pierwszy, jest uniwersytet w Bolonii. Drugim, który podobnie jak boloński przyczynił się w znacznym stopniu do rozwoju szkolnictwa europejskiego, kultury oraz nauki był uniwersytet w Paryżu. W Italii powstał, w roku 1173, uniwersytet w Salerno, natomiast w krajach północnych najstarszy był uniwersytet w Oksfordzie. Wiek XIII-XV to czas wielkiego rozkwitu uniwersytetów w Europie. Warto wspomnieć chociażby rok 1209, kiedy to powołano do życia uniwersytet w Cambridge. Na kontynencie europejskim, w wyżej wymienionym przedziale czasowym, uniwersytety były już prawie w każdym kraju. W 1222 roku powstał uniwersytet w Padwie, w 1224 w Neapolu, w 1240 w Sienie, w roku 1303 w Rzymie i w 1308 w Perugi. We Francji uniwersytety zaczęły powstawać nie tylko w Paryżu, ale także poza nim, jak choćby w Anders i Tuluzie (1229), w Montpellier (1289), w Awinionie (1303), Orleanie (1309), czy wreszcie w Grenoble, w 1339 roku. W środkowej Europie, w 1348 roku założono uniwersytet w Pradze, w 1364 roku w Krakowie oraz 1365 roku w Wiedniu.

15 S.I. Możdżeń, Historia wychowania do 1975, Sandomierz 2006, s. 166.

${ }^{16}$ S. Litak, Historia wychowania. Do wielkiej rewolucji francuskiej, Kraków 2006, s. 67.

17 B. Milerski, B. Śliwerski (red.), Pedagogika. Leksykon PWN, s. 254.

${ }^{18}$ T. Lewowicki, Ksztatcenie uniwersyteckie - siła tradycji, presja wspótczesności, pytania o przyszłość, przestania, [w:] Uniwersytet. Społeczeństwo. Edukacja, red. W. Ambrozik, K. Przyszczypkowski, Poznań 2004, s. 43-50.

${ }^{19}$ J. Baszkiewicz, Młodość uniwersytetu, Warszawa 1963, s. 8. 
To do uniwersytetów należy misja podtrzymywania dorobku nauki i kultury oraz tworzenie nowej wiedzy i jej upowszechnianie ${ }^{20}$. To również pielęgnowanie tradycji i obyczajowości ${ }^{21}$. Jerzy Brzeziński wyróżnił cztery podstawowe wartości określające uniwersytet: autonomię, różnorodność, komplementarność badania i nauczania oraz prawdę polegającą na doskonaleniu warsztatu badawczego oraz rozwijaniu świadomości metodologicznej ${ }^{22}$. Zdaniem Czesława Kupisiewicza, to uniwersytetom zawdzięczamy wprowadzenie do akademickiej praktyki edukacyjnej istniejącej do dziś gradacji stopni naukowych oraz metodyczne instrumentarium ich pozyskiwania w postaci wykładów, ćwiczeń, dyskusji i różnego rodzaju prac, zaczynając od seminaryjnych, po doktorskie, a kończąc na habilitacyjnych. Oprócz tego, uniwersytetom zawdzięczamy respektowanie zasady współpracy wykładowców ze studentami, autonomię badań naukowych oraz metodę rozwijania problemów $\mathrm{w}$ drodze dysput, które z czasem nazwano scholastycznymi ${ }^{23}$.

Kazimierz Denek w książce Uniwersytet w perspektywie społeczeństwa wie$d z y$. Nauka i edukacja w uniwersytecie XXI wieku pisząc o uniwersyteckim etosie i jego „obywatelskiej” oraz „kulturowej” misji stwierdził, iż uniwersytet ma zadanie

wytwarzania, poznawania, przekazywania, upowszechniania wiedzy, utrzymywania ciągłości historyczno-kulturowej narodu; kreowania wzorców zachowań ludzkich i postaw obywatelskich; wychowywania ludzi światłych, mądrych i oddanych Polsce ${ }^{24}$.

Całe szkolnictwo wyższe, $w$ tym i uniwersytety, to miejsca promowania podnoszenia i dbałości o jakość wiedzy ${ }^{25}$. To wreszcie miejsca

przygotowujące studentów do tego, by pełnić w sposób bardziej sprawny i efektywny szeroki zakres obywatelskich i profesjonalnych funkcji i czynności, nawet najbardziej zróżnicowanych ${ }^{26}$.

\footnotetext{
${ }^{20}$ A. Orczyk, Zarys historii szkolnictwa i myśli pedagogicznej, Warszawa 2008, s. 67-75.

${ }^{21}$ T. Lewowicki, Ksztatcenie uniwersyteckie - sita tradycji, s. 43-50.

${ }^{22}$ J. Brzeziński, Trwałe wartości uniwersytetu, Forum Oświatowe, 1997, t. 1-2, s. 211-218.

${ }^{23}$ Cz. Kupisiewicz, Szkice z dziejów dydaktyki, Kraków 2010, s. 29.

${ }^{24}$ Zob. K. Denek, Uniwersytet w perspektywie społeczeństwa wiedzy. Nauka i edukacja w uniwersytecie XXI wieku, Poznań 2011, s. 63.

${ }^{25}$ Zob. T. Wawak (red.), Wyzwania zarządzania jakościa w szkołach wyższych, Kraków 2011; J. Woźnicki, Uczelnieakademickiejako instytucjeżyciapublicznego, Warszawa 2007; M. Dąbrowa-Szefler, J. Jabłecka, Szkolnictwo wyższe w Polsce. Raport dla OECD, Warszawa 2007; K. Lisiecka (red.), Zapewnienie jakości ksztatcenia w szkole wyższej, Katowice 2001; M. Wójcicka (red.), Jakość kształcenia w szkolnictwie wyższym. Stownik tematyczny, Warszawa 2001; E. Wnuk-Lipińska, M. Wójcicka (red.), Jakość w szkolnictwie wyższym. Przykład Polski, Warszawa 1995; A. Brzezińska, J. Brzeziński, A. Eliasz (red.), Ewaluacja a jakość kształcenia w szkole wyższej, Warszawa 2004; A. Brzezińska, J. Brzeziński (red.), Ewaluacja procesu kształcenia w szkole wyższej, Poznań 2000.

${ }^{26}$ K. Denek, Edukacja. Dziś-jutro, Leszno - Poznań - Żary 2006, s. 108-109.
} 
Zbyszko Melosik prawidłowe funkcjonowanie uniwersytetów upatruje $\mathrm{w}$ akademickiej wolności ${ }^{27}$. Wolność przejawiająca się w zakresie badań naukowych i upowszechniania ich wyników (naukowcy mają prawo do wyboru własnego przedmiotu badań), to także wolność w sferze nauczania ${ }^{28}$. Ponadto, naukowcy i nauczyciele akademiccy mają prawo do swobodnych wypowiedzi na publiczne tematy, a także wyrażania swoich opinii na temat polityki edukacyjnej oraz instytucjonalnych priorytetów szkól, których są pracownikami ${ }^{29}$.

Literatura przedmiotu przedstawia różne modele uniwersytetów: francuski, angielski, niemiecki ${ }^{30}$, które charakteryzowały się zróżnicowanym podejściem do misji, jaką ma do spełnienia uniwersytet. Autorzy modeli wskazywali ich główne zadania. I tak: w modelu francuskim i angielskim najważniejsze było kształcenie wąskoprofilowe, z kolei w modelu niemieckim kładziono nacisk na prowadzenie badań naukowych. Dominujące $\mathrm{w}$ Europie modele uniwersytetu, angielski i niemiecki, ukształtowały wspólną koncepcję kształcenia akademickiego, której fundament stanowiło odrzucenie idei kształcenia zawodowego studentów na rzecz poszukiwania i dążenia do prawdy, a realizacja tych celów związana została z prowadzeniem badań naukowych. Współczesny uniwersytet, jak wskazuje Mieczysław Malewski, ma hybrydowy charakter ${ }^{31}$ - oprócz badań oferuje szeroko rozumiany rozwój, przez co stwarza możliwość zindywidualizowania ścieżek kształcenia.

Uniwersytet jako instytucja szkolnictwa wyższego, na tle pozostałych instytucji ekonomicznych, politycznych, religijnych, wyróżniał się systemem wartości, swoją majestatycznością, ale także ograniczonym dostępem, bowiem uczestnictwo w życiu akademickim wymagało potwierdzenia predyspozycji osobowościowych i intelektualnych, zarówno ze strony studentów, jak i samych akademików. Obecnie dynamiczny rozwój wszystkich aspektów życia wpłynął na ewolucję roli uczelni wyższych na przestrzeni ostatnich lat, wyznaczając nowy kierunek działań, zmianę narzędzi i sposobów nauczania. Uniwersytet stracił wyłączność w zakresie definiowania tego, co jest wiedzą wartościową; wpisuje się w politykę globalnego rynku i staje się

${ }_{27}$ Zob. Z. Melosik, Uniwersytet i społeczeństwo. Dyskursy wolności, wiedzy i władzy, Kraków 2009; J. Kostkiewicz (red.), Uniwersytet i wartości, Kraków 2007; C. Kościelniak, J. Makowski (red.), Wolność. Równość. Uniwersytet, Warszawa 2011.

28 Z. Melosik, Uniwersytet i społeczeństwo, s. 11.

29 Tamże, s. 12.

30 A. Sajdak, Paradygmaty ksztatcenia studentów i wspierania rozwoju nauczycieli akademickich. Teoretyczne podstawy dydaktyki akademickiej, Kraków 2013, s. 103-110.

31 M. Malewski, Czy koniec ery akademickich podręczników? Teraźniejszość - Człowiek - Edukacja, 2008, 4(44), s. 99. 
usługodawcą ${ }^{32}$. Wiedza powstająca na uniwersytetach staje się towarem, jest w pewnym stopniu odpowiedzią na potrzeby rynku pracy, a dokładnie instytucji, przedsiębiorstw, korporacji i rządów, które przetwarzają ją w zależności od potrzeb, a następnie nadają jej określoną wartość. Rynek pracy „zgłasza zapotrzebowanie" na określony typ absolwenta, wyposażonego w konkretne umiejętności i wiedzę, i to on staje się "produktem” końcowym kształcenia akademickiego. Współczesny uniwersytet nie funkcjonuje w oderwaniu i separacji od społeczeństwa, przeciwnie - coraz bliżej współpracuje z otoczeniem zewnętrznym. Szczególnego znaczenia nabierają relacje i powiązania $\mathrm{z}$ istniejącymi instytucjami, przedsiębiorcami, inkubatorami przedsiębiorczości, centrami transferu wiedzy i technologii. Uniwersytety mają kształtować ludzi nie tylko posiadających wiedzę i zdolnych do jej przyswajania, ale także otwartych, przedsiębiorczych i nade wszystko kreatywnych ${ }^{33}$.

Równolegle ze zmianą funkcjonowania uniwersytetu na zewnątrz, zachodzi zmiana wewnętrzna. Zmianie ulega sposób finansowania - dotacje z budżetu państwa nie zawsze są wystarczające ${ }^{34}$ i dlatego też uczelnie poszukują innych źródeł. Wiąże się to z pozyskiwaniem funduszy na badania z NCNu, FNP, czy MNiSW ${ }^{35}$ poprzez aplikowanie w ogłaszanych konkursach. Środki na badania otrzymają te uczelnie, lub ci naukowcy, którzy spełnią określone wymagania i złożą stosowny, spełniający kryteria, wniosek przedstawiający plan zamierzonych eksploracji badawczych. Zaistniała sytuacja pokazuje konieczność zwiększenia aktywności uczelni, jak i naukowców, ale wskazuje także na coraz bardziej widoczne podejście ekonomiczno-menadżerskie w zarządzaniu uczelnią wyższą. Pozyskane fundusze pozwalają na finansowanie i przeprowadzenie badań naukowych, a w kontekście czysto rynkowym po prostu kreują miejsce pracy i zapewniają wynagrodzenie pracownikom naukowym.

Zmiana sposobu myślenia o uniwersytetach wiąże się również ze zmianą sposobu myślenia o postaci dydaktyka - naukowca. Na przestrzeni ostatnich dwudziestu lat można dostrzec bardzo widoczne zmiany w zakresie oczekiwania władz uczelni i studentów wobec kadry naukowo-dydaktycznej. Wynikają one ze zmian społeczno-kulturowych, ale także uwarunkowań prawnych i zmian legislacyjnych.

${ }^{32}$ Z. Melosik, Uniwersytet i społeczeństwo, s. 61-65.

${ }^{33}$ K. Dyrtkowski, M. Popek, Uwagi o przedsiębiorczości uczelni w modelu uniwersytetu III generacji, [w:] Uniwersytet trzeciej generacji. Stan i perspektywy rozwoju, red. D. Burawski, Poznań 2013, s. 61.

${ }^{34}$ K. Łyszczarz, Finansowanie uczelni publicznych a przedsiębiorczość akademicka, Ekonomia i Zarządzanie, 2013, 1, s. 41.

${ }^{35}$ Narodowe Centrum Nauki, Fundacja na rzecz Nauki Polskiej, Ministerstwo Nauki i Szkolnictwa Wyższego. 


\section{Praca na uniwersytecie. Kim jest obecnie nauczyciel akademicki?}

Praca naukowa na uniwersytecie w społecznej opinii to prestiż, ale także ogromna odpowiedzialność. Specyfika pracy na uczelni uzależniona jest od jej profilu. Na przestrzeni wieków uległa ona znacznym przemianom. Podjęcie dyskusji na temat pracy nauczyciela akademickiego - jego ról, funkcji, zadań, cech osobowych i kompetencji - jest niezwykle ważne, zwłaszcza w sytuacji kiedy coraz głośniej mówi się o upadku uniwersytetów, ich kryzysie lub przynajmniej o przeminięciu czasu ich świetności. Pracownicy naukowodydaktyczni stanowią o potencjale badawczym swojej Alma Mater, a dyskurs odnoszący się do ich holistycznego funkcjonowania w obszarze nauki i dydaktyki, a raczej pomiędzy nimi stanowi istotny wkład w rozwój tej profesji.

W Klasyfikacji Zawodów i Specjalności nauczyciel akademicki znajduje się w grupie zawodowej „specjaliści”, a dokładnie specjaliści nauczania i wychowania, gdzie opisany został pod numerem $2310^{36}$, a szczegółowe dziedziny nauk od numer 231001-231021 i $231090^{37}$. Grupa ta obejmuje zawody wymagające posiadania wysokiego poziomu wiedzy zawodowej, umiejętności oraz doświadczenia w zakresie nauk technicznych, przyrodniczych, społecznych, humanistycznych i pokrewnych. Ich głównymi zadaniami są: wdrażanie do praktyki koncepcji i teorii naukowych lub artystycznych, powiększanie dotychczasowego stanu wiedzy poprzez badania i twórczość oraz systematyczne nauczanie w tym zakresie ${ }^{38}$. Z kolei, zgodnie z brzmieniem artykułu 108 Ustawy o szkolnictwie wyższym nauczycielami akademickim są pracownicy naukowo-dydaktyczni, pracownicy dydaktyczni, pracownicy naukowi i dyplomowani bibliotekarze oraz pracownicy dokumentacji i informacji naukowej ${ }^{39}$.

Dla potrzeb niniejszego artykułu skupiono się na pracowniku dydaktyczno-naukowym, który stanowi najsilniej reprezentowaną grupę pracowników na uniwersytetach i zdaje się być wspomnianą hybrydą w zakresie obowiązków wymienionych wcześniej grup pracowniczych. Zgodnie z Ustawą do podstawowych obowiązków pracowników naukowo-dydaktycznych należy kształcenie i wychowywanie studentów, prowadzenie badań naukowych, a także uczestnictwo $\mathrm{w}$ pracach organizacyjnych uczelni ${ }^{40}$. Ma on także prze-

${ }^{36}$ Klasyfikacja zawodów i specjalności na potrzeby rynku pracy, Warszawa 2014, s. 39.

37 Tamże.

${ }^{38}$ Rozporządzenie Ministra Pracy i Polityki Społecznej z 7 sierpnia 2014 w sprawie klasyfikacji zawodów i specjalności na potrzeby rynku pracy oraz zakresu jej stosowania, s. 72 (DzU z 2014, poz. 1145).

39 Art. 108, Ustawa z 27 lipca 2005 roku Prawo o szkolnictwie wyższym, DzU z 2005, nr 164, poz. 1365 z późn. zm.

40 Art. 111, Ustawa z 27 lipca 2005 roku Prawo o szkolnictwie wyższym, DzU z 2005, nr 164, poz. 1365 z późn. zm. 
kazywać wiedzę, poszerzać horyzonty studenta, nadzorować jego pracę badawczo-dydaktyczną, walczyć ze stereotypami, krzewić zasadę tolerancji dla rzeczy i ludzi odmiennych, uczyć szacunku i skromności, być wzorem etyki i moralności, oraz propagować konstruktywną krytykę ${ }^{41}$.

Większości społeczeństwa pracownik naukowy uniwersytetu kojarzy się z osobą posiadającą tytuł profesora i zgodnie z badaniami CBOS z 2013 roku" cieszy się szacunkiem, a o jego wysokiej pozycji decyduje przede wszystkim ekspercki charakter profesji oraz długoletnia tradycja, przypisująca jej wysoki prestiż społeczny. Istotnym czynnikiem statusu jest $w$ tym wypadku zarówno sam tytuł naukowy oraz płynący stąd autorytet, jak i rodzaj pracy kojarzony z niezależnością intelektualną. Niezależność intelektualna oraz prowadzenie badań naukowych stanowi niekwestionowaną wartość dla procesu kształcenia na poziome akademickim. Mistrz - Mentor - Nauczyciel przekazywał prawdy o wszechświecie i zachęcał do zgłębiania reguł rządzących światem. Obecnie zamiast mentora i mistrza, który ofiaruje wiedzę oraz prawdę o życiu i świecie, studenci poszukują informatora-specjalisty, który przekaże im wiedzę specjalistyczną i w pełni użyteczną ${ }^{43}$. Studenci oczekują osób dynamicznych, podążających za nowościami, przedsiębiorczych, twórczych w swojej pracy, ale także potrafiących przekazywać posiadaną wiedzę, włączających ich w swoje działania naukowe, potrafiących odpowiedzieć na ich potrzeby. Ponadto, nauczyciel akademicki powinien posiadać wiedzę z zakresu zarządzania, a także skutecznego i efektywnego kierowania grupą ${ }^{44}$, co znajduje swoje uzasadnienie w odniesieniu do zmian zachodzących na uniwersytecie. W takim ujęciu nauczyciel akademicki staje się organizatorem, kierownikiem i kontrolerem procesu dydaktycznego ${ }^{45}$, a także jego opiekunem ${ }^{46}$. Co istotne, jest najważniejszym składnikiem systemu edukacji i w funkcjonowaniu tego systemu spełnia rolę strategiczną ${ }^{47}$. Należy jednak pamiętać, iż ów nauczyciel jest także pracownikiem, toteż winien spełniać oczekiwania nie tylko studentów, ale i swojego pracodawcy. Wywiązywać się ze wszystkich powierzonych mu obowiązków.

${ }^{41}$ P. Kaptur, Idealny nauczyciel akademicki - mit czy realizm?, Forum Oświatowe, 2011, 1(44), s. 71.

${ }^{42}$ Centrum Badania Opinii Społecznej, Komunikat z badań Prestiż zawodów, Warszawa 2013.

${ }^{43}$ Z. Melosik, Uniwersytet i społeczeństwo, s. 64.

${ }^{44}$ A. Sajdak, Paradygmaty ksztatcenia studentów, s. 119.

45 P. Kaptur, Idealny nauczyciel, s. 73.

${ }^{46}$ S. Wołoszyn, Nauczyciel i elementy wiedzy o nauczycielu, [w:] Pedagogika, red. B. Suchodolski, Warszawa 1985, s. 698.

${ }_{47}$ R. Stankiewicz, Nauczyciel w czasach II Rzeczypospolitej, [w:] Nauczyciel - opiekun - wychowawca. Tradycje - teraźniejszość - nowe wyzwania, red. R. Stankiewicz, Poznań - Zielona Góra 2002, s. 13. 
Kim zatem jest lub ma być współczesny nauczyciel akademicki? Z rozmów prowadzonych ze studentami wyłania się dość czytelny w ich ocenie obraz wykładowcy. W oczach studentów jest to osoba, która przychodzi na wykłady, konwersatoria, seminaria, laboratoria, dyżury, a po ich odbyciu wraca do domu ciesząc się czasem wolnym. Studenci zdają się nie zauważać, a przede wszystkim nie znać, specyfiki pracy nauczyciela akademickiego. Nie dostrzegają konieczności łączenia przez wykładowców trzech podstawowych elementów: dydaktyki, pracy naukowej i życia osobistego. $Z$ racji tego, iż studenci mają określone i coraz częściej bardzo wygórowane wymagania względem zajęć, wykładowca jest zobowiązany do ciągłego aktualizowania swojej wiedzy, poszukiwania i wykorzystywania nowoczesnych metod nauczania (w tym nowoczesnych technologii), które spełnią oczekiwania studentów-klientów, traktujących uniwersytet jak sklep ${ }^{48}$.

Podjęcie pracy na uniwersytecie czy też uczelni wyższej wiąże się z przyjęciem określonego stylu życia. Elementami budującymi styl akademicki jest niewątpliwie stosunek do wykonywanej pracy, identyfikacja jednost$\mathrm{ki}$, zaspokajanie potrzeb intelektualnych, szeroko rozumiane uczestnictwo w kulturze i życiu społeczno-politycznym, a także zachowania rekreacyjne. Przyjęcie takiego sposobu myślenia o pracy naukowo-dydaktycznej wpływa na społeczny odbiór tej profesji. Względem nauczycieli akademickich społeczeństwo formułuje określone oczekiwania - powinni oni stanowić przykład zachowań, na których może wzorować się młode pokolenie. Za najważniejsze cechy dobrego nauczyciela akademickiego uznaje się duży zasób wiedzy, łatwość nawiązywania kontaktów, wysoki poziom moralny (etyczny), tolerancję, rzetelność i sumienność, konsekwencje, wysoką kulturę osobistą. W literaturze opisującej wykładowców „idealnych” i poszukiwanych znajdziemy także takie cechy i przymioty, jak: cierpliwość, skromność, odpowiedzialność, uczciwość, niezależność, pasja, punktualność, zaangażowanie, mobilność, odwaga, refleksja, chart ducha, silny charakter, powaga. Ponadto, cechami pożądanymi są: wysokie kompetencje, kultura osobista, postawa twórcza, aktywna, kreatywna, spostrzegawczość, wyrozumiałość, tolerancyjność, autentyczność, otwartość, akceptacja, obiektywizm. W pracy nauczyciela akademickiego - dydaktyka ważne są nie tylko wiedza oraz dobre przygotowanie pedagogiczne. Niezwykle cenną cechą jest talent pedagogiczny, rozumiany jako pewien wyższy stopień uzdolnienia do jakiejś działalności, a nie wrodzona dyspozycja ${ }^{49}$.

${ }^{48}$ W. Sztumski, Student-klient, Sprawy Nauki, 2013, 8/9, (182).

${ }^{49}$ E. Kiełb-Starczewska, Nauczyciel w transformacjach cywilizacyjnych, [w:] Być nauczycielem. Kompetencje wspótczesnego nauczyciela, red. M. Cywińska, Poznań 2013, s. 42-43. 
Pracownicy uczelni powinni dawać wzór nie tylko na uczelni, podczas wykładów, ćwiczeń i seminariów, ale również poza uczelnią ${ }^{50}$. Mowa tu także o kształceniu zgodnie z oczekiwaniami powszechnie aprobowanymi w społeczeństwie (związanymi z postawami moralnymi, poszanowaniem godności, szacunkiem wobec własnego kraju i innych odmiennych kulturowo, religijnie i obyczajowo, z uwzględnieniem sprawiedliwości, tolerancji) ${ }^{51}$. Pogodzenie oczekiwań społecznych z zaspokojeniem potrzeb własnych jest jednym z trudniejszych zadań, przed jakimi staje jednostka. Wytężony wysiłek umysłowy związany z długoterminową koncentracją jest niezwykle męczący. Zaangażowanie, napięcie i presja czasu powodują, że jest on porównywalny, a niekiedy nawet bardziej dokuczliwy niż wysiłek fizyczny. Jest to niewątpliwie praca, która daje dużo satysfakcji, ale niesie ze sobą także wiele wysiłku i poświęceń. Nieodłączny jej element stanowi permanentna edukacja, poszerzanie swoich kwalifikacji i kompetencji, które wymagają czasu i zaangażowania. Ponadto, częstym zjawiskiem jest „zabieranie pracy” do domu, związane ze sprawdzaniem prac (w szczególności prac licencjackich i magisterskich), kolokwiów, egzaminów, ale także przygotowywaniem się do zajęć, opracowywaniem programów i planów studiów. Istotnym czynnikiem, który należy uwzględnić jest także liczba podopiecznych. Liczba studentów przypadająca na nauczyciela akademickiego "humanistę" jest większa niż na opiekuna naukowego z zakresu nauk ścisłych, skutkuje to w związku z powyższym innym nakładem czasu pracy.

Praca na uczelni $\mathrm{w}$ ujęciu potocznym to praca na etacie, ale zdecydowanie nie etatowa. Jak studiowanie, które nie zaczyna się i nie kończy na zajęciach, lecz trwa nieustannie ${ }^{52}$, tak praca naukowca - dydaktyka wykracza zdecydowanie poza standardowe godziny pracy i czas przebywania na terenie uczelni. Nauczyciel akademicki ma możliwość ustalenia godzin porannych, popołudniowych lub, jeśli istnieje taka możliwość, przeznaczenia w całości jednego lub dwóch dni w tygodniu na zajęcia dydaktyczne i spotkania naukowe. Jednakże, często ograniczony liczbą pomieszczeń, jaką dysponuje dana uczelnia, prowadzi zajęcia w godzinach wieczornych. Praca akademika - dydaktyka jest niezwykle ciekawa i rozwijająca. Może się wydawać, że nauczanie tego samego przedmiotu przez kilkanaście semestrów jest nudne i sprzyja wypaleniu zawodowemu, jednak należy pod-

50 A. Piwowar, Kariera na uczelni jako nauczyciel akademicki, 2010, dokument elektroniczny, pobrano ze strony: https://www.careers.uni.wroc.pl/media/uploads/karieraakadem.pdf [20.12.2017].

${ }^{51}$ K. Janus, Stownik pedagogiki i psychologii. Zagadnienia, pojęcia, terminy, Warszawa 2011, s. $165-166$.

${ }^{52}$ W. Żłobicki, Podmiotowość człowieka jako podstawa edukacji akademickiej, [w:] Problemy edukacji w szkole wyższej, red. A. Szerląg, Kraków 2006, s. 193. 
kreślić, że za każdym razem jest to nowa grupa studentów, która omawianą problematykę postrzega inaczej, analizowane treści ulegają zmianom - muszą być aktualizowane, forma zaliczenia i sposób prowadzenia zajęć może być inny. W zależności od polityki prowadzonej w pracowniach, zakładach, instytutach, czy katedrach, pracownicy mogą wymieniać się przedmiotami bądź prowadzić je w ramach zastępstwa (za innego pracownika przebywającego na urlopie naukowym lub zdrowotnym) - pozwala to uniknąć wspomnianego wypalenia zawodowego, zniechęcenia i schematycznego wykonywania obowiązków. Ponadto, nauczyciele akademiccy mogą wpływać na rozszerzenie oferty edukacyjnej poprzez prowadzenie przedmiotów fakultatywnych, nie związanych bezpośrednio z programem studiów, ale związanych z ich zainteresowaniami, co jest wyrazem ich samodzielności, kreatywności, autonomii i przekłada się w znaczącym stopniu na satysfakcję z wykonywanej pracy.

Sfera pracy naukowej nauczyciela akademickiego jest mało znana studentom i ogółowi społeczeństwa. Stwierdzenie, jakie niejednokrotnie zdarzyło się słyszeć wykładowcom, mówiącym, czym zajmują się zawodowo brzmi: "Wy to macie dobrze, tyle wolnego...". Ale czy naprawdę tak jest? Czas wolny jest tu pojęciem względnym. Oczywiście, okresy świąt oraz letnich wakacji są czasem wolnym, ale wolnym od zajęć dydaktycznych. Bardzo duża część zadań bywa realizowana właśnie w tak zwanym „czasie wolnym" w okresie wakacji, weekendów i świąt, ponieważ obwarowana jest określonymi terminami. Warto zaznaczyć, iż wykładowca pracuje niejednokrotnie także w soboty i niedziele, prowadząc zajęcia na studiach niestacjonarnych i podyplomowych. Niewątpliwie, jest to praca w systemie 24/7. Zarówno dydaktyka, jak i aktywność naukowa wymagają przygotowania, zapoznania się z literaturą przedmiotu, opracowania metodologii, co także zajmuje sporo czasu. Ponadto, pracownicy dydaktyczno-naukowi są opiekunami grup studentów, nadzorują układanie planów zajęć, a także rozwiązują problemy, na które napotykają studenci, tworzą programy kształcenia i sylwetki absolwentów, które wymagają ustawicznej aktualizacji zgodnie z wymaganiami zmieniającej się rzeczywistości. Piastują funkcje sekretarzy różnego rodzaju komisji, opiekunów praktyk, nawiązując pracę z otoczeniem zewnętrznym i wyjeżdżając ze studentami na praktyki terenowe bądź zajęcia hospitacyjne, a także opiekunów kół naukowych, biorą aktywny udział w komisjach rekrutacyjnych, działających właśnie w okresie wakacyjnym.

Nieodłącznym elementem pracy na uczelni, oprócz prowadzenia zajęć i odbywania dyżurów, o który pracownik nauki musi zadbać jest jego rozwój i awans zawodowy. Wymagania kierowane w stosunku do pracowników nauki są zróżnicowane ze względu na dziedzinę nauki, jednak wiele kryteriów 
jest tożsamych ${ }^{53}$. Na dorobek naukowy składa się między innymi autorstwo publikacji naukowych (artykułów, monografii), udział w międzynarodowych i krajowych konferencjach oraz sympozjach, opieka naukowa nad studentami (w tym promotorstwo prac licencjackich/magisterskich), staże i wyjazdy krajowe oraz zagraniczne (krótko- lub długoterminowe) rzutują na tryb życia codziennego. Sytuacja ta jest zdecydowanie trudniejsza w przypadku kobiet - naukowczyń, na którą składają się udział w projektach badawczych i zespołach eksperckich, udział w komitetach redakcyjnych, recenzowanie projektów, nagrody, wyróżnienia, wynalazki i patenty. Wspomniane wcześniej wyjazdy krajowe i zagraniczne (konferencje, seminaria, staże), zwłaszcza kilkudniowe i długookresowe, stanowią przysłowiowe łączenie przyjemnego z pożytecznym. Dają możliwość nie tylko rozwoju zawodowego w szerokim znaczeniu tego słowa (prowadzenie badań, wymiana doświadczeń z innymi naukowcami oraz nawiązania z nimi naukowej współpracy), ale także podróżowania, poznawania nowych kultur oraz w mniejszym stopniu odwiedzenia ciekawych miejsc i odpoczynku.

\section{Nauczyciel akademicki od A do Z vs epizodysta naukowy}

Role zawodowe, $\mathrm{w}$ jakie wchodzi nauczyciel akademicki nie zawsze są spójne, a zdarza się, że pozostają wzajemnie w swego rodzaju konflikcie, co powoduje niewątpliwie dyskomfort. Nie każdy naukowiec jest dobrym dydaktykiem i odwrotnie. Warto nieco bliżej przyjrzeć się nauczycielowi akademickiemu funkcjonującemu w poszczególnych rolach zawodowych, aby na tej podstawie dokonać próby ukazania niektórych dylematów przedstawicieli tej kategorii społeczno-zawodowej.

Analizując literaturę dotyczącą uniwersytetów, wykładowców oraz inspirując się tytułem znanej książki Czesława Banacha ${ }^{54}$, podjęliśmy próbę wyliczenia i opisania wraz z uzasadnieniem ról pełnionych przez akademików, zdając sobie sprawę, że wachlarz ten jest otwarty.

- Autor. Zgodnie z sentencją „Publish or perish"55, publikuj albo znikniesz, $\mathrm{w}$ pracy akademika istotne są cytowania. Fraza ta podkreśla konieczność rozpowszechniania swojego dorobku naukowego na gruncie krajowym, jak i międzynarodowym. Krytycy tego zjawiska niejednokrotnie wskazują

${ }^{53}$ Rozporządzenie Ministra Nauki i Szkolnictwa Wyższego z 1 września 2011 roku w sprawie kryteriów oceny osiągnięć osoby ubiegającej się o nadanie stopnia doktora habilitowanego (DzU nr 196, poz. 1165).

${ }^{54}$ Cz. Banach, Nauczyciel naszych oczekiwań i potrzeb od A do Ż, Lublin 2009.

55 Źródło internetowe: https://www.oxfordlearnersdictionaries.com/definition/english/ publish-or-perish [12.12.2017]. 
negatywny wpływ na jakość dydaktyki. Parametryzacja i konieczność zdobywania punktów za publikacje (najlepiej z naukowcami z innego ośrodka, ponieważ to jest bardziej „opłacalne") powoduje znaczne obniżenie jakości nauczania. Po prostu, na przygotowanie się do zajęć brakuje czasu. Publikowanie na potęgę, bo nie można tego zjawiska nazwać inaczej, wydaje się nie mieć głębszego sensu, ponieważ jak wskazuje Z. Bauman za Eriksenem: „ponad połowa artykułów socjologicznych publikowanych w czasopismach naukowych nie jest nigdzie cytowana" ${ }^{56}$, treść artykułu znana jest anonimowym recenzentom. Zatem, nasuwa się pytanie, jaki jest wkład autorów w dyskurs określonych nauk?

- Biznesmen (Praktyk). Ważnym elementem pracy współczesnego wykładowcy akademickiego jest współpraca z otoczeniem gospodarczym, z interesariuszami. Realizowanie na rzecz sektora biznesu zleceń, opracowywanie procedur, metod i technik. Pracownicy nauki na zamówienie przeprowadzają szkolenia i warsztaty. Aspekt praktyczny tej roli jest widoczny w oczekiwaniach i ocenach studentów. Zajęcia z praktykami cieszą się uznaniem studentów i zyskują wysokie noty w rankingach oraz badaniach jakości kształcenia.

- Czciciel (Pasjonat). Entuzjasta swojej pracy. Zajęcia ze studentami traktuje nie jako obowiązek, a możliwość przekazania wiedzy teoretycznej oraz praktycznej. Przekazuje ją często w sposób niesztampowy. Jest kreatywny. Tok prowadzonych zajęć ma charakter poszukujący bądź problemowy. Daleki jest od toku zajęć podających. Ceni dialog, jest aktywnym słuchaczem. Nie ocenia, nie wartościuje poglądów studentów.

- Doradca. W kontekście doradztwa akademickiego i efektywnego wykorzystywania czasu studiów ${ }^{57}$ wykładowca akademicki powinien doradzić studentowi, w jaki sposób może wykorzystać swój potencjał i rozwijać posiadane już umiejętności. Taki rodzaj aktywności akademika wpisuje się w doradztwo zawodowe sensu largo ${ }^{58}$.

- Ekspert. Specjalista w swojej dziedzinie. Na prowadzonych przez siebie zajęciach wykorzystuje wiedzę z własnych badań oraz skonkretyzowanych publikacji. Często cytowany, szanowany w akademickiej społeczności. Pro-

${ }^{56}$ Z. Bauman, Wyzwania dla edukacji w dobie ptynnej nowoczesności, [w:] Uniwersytety, naukowcy i studenci w zglobalizowanym świecie, red. R. Siemieńska, Warszawa 2017, s. 17.

${ }_{57}$ M. Rosalska, Doradztwo akademickie w kontekście kształtowania kapitału profesjonalnego studentów, Dyskursy Młodych Andragogów, 2013, 14.

${ }^{58}$ Profesjonalne doradztwo zawodowe dzieli się na dwie kategorie. Pierwsza to doradztwo zawodowe sensu stricto związane bezpośrednio z wykonywanym zawodem konsultingowym jakim jest doradca zawodowy, drugim typem doradztwa profesjonalnego jest doradztwo typu sesnu largo, które jest elementem składowym innej roli zawodowej uprawniającym do udzielania porad, np. lekarz, pośrednik pracy, urzędnik, czy nauczyciel. Zob. A. Bańka, Zawodoznawstwo, doradztwo zawodowe, pośrednictwo pracy. Psychologiczne metody i strategie pomocy bezrobotnym, Poznań, 2005, s. 26. 
szony o wydawanie opinii czy też ekspertyz w sprawach ważnych społecznie. Osoba wyjaśniająca ogółowi społeczeństwa zachodzące procesy, ich znaczenie, przyczyny i skutki.

- Figurant (Zastępowy). Bezkompromisowy Gianfranco Gambarelli, profesor z Uniwersytetu w Bergamo, karierę nauczyciela akademickiego kreśli jako drogę niełatwą, gdyż „Asystent wie wszystko; adiunkt wie, w których książkach można wszystko znaleźć, a profesor wie, gdzie znaleźć adiunkta" 59 . Figurant prowadzi zajęcia zastępując profesora, swoich współpracowników. Są to zarówno wykłady, ćwiczenia, jak i zajęcia fakultatywne.

- Generalny Menadżer (z ang. General Manager ${ }^{60}$. W kontekście szkolnictwa wyższego rektor zarządzający uczelnią, dziekan sprawujący władzę nad wybraną jednostką (wydział) lub kierownik nadzorujący pracę katedry, zakładu, instytutu, pracowni. To strateg, dyrektor, zarządca i pracodawca odpowiedzialny między innymi za zatrudnianie pracowników, prowadzenie działań strategicznych z punktu widzenia prowadzonej komórki, motywowanie kadry i monitorowanie jej pracy oraz reprezentowanie instytucji na zewnątrz. Literatura wskazuje, że uniwersytet wpisuje się w politykę globalnego rynku i staje się partnerem biznesowym oraz w pewnym stopniu usługodawcą. Taki sposób funkcjonowania uczelni wymaga także zmiany sposobu jej prowadzenia, co wyraźnie podkreśla Łukasz Sztern, pokazując ewolucję roli rektora od kanclerza do menadżera ${ }^{61}$.

- Handlowiec. Propagator. RP-owiec. Do obowiązków pracowników dydaktyczno-naukowych należy partycypowanie $\mathrm{w}$ pracach organizacyjnych uczelni. Podczas różnego rodzaju eventów; targów edukacyjnych, festiwali, konkursów zachęcają do podjęcia studiów na ich uczelni, reklamują dany kierunek kształcenia, odwiedzają swoje szkoły. Zgodnie z obowiązującą, aczkolwiek nie pisaną, rynkową zasadą są wizytówką swojego pracodawcy.

- Inspirator. „Kto chce zapalać innych, sam musi płonąć”62. Maksyma ta wyraźnie akcentuje prawdziwe zaangażowanie nauczyciela akademickiego w swoją pracę. Akademik winien być także animatorem, inicjatorem, kreatorem, modernizatorem, pionierem, pomysłodawcą, propagatorem, a także prowokatorem. Między wykładowcą a studentem powinien wytworzyć się specyficzny rodzaj chemii, dzięki której żakom „będzie się chciało chcieć", będą szukać sposobów a nie powodów. Budować i popularyzować

${ }^{59}$ G. Gambarelli, Wspinaczka po profesurę. Przewodnik satelitarny po karierze akademickiej - od upadków na kolana i ciosów w plecy do zaszczytów, Warszawa 2011, s. 15.

${ }^{60}$ Źródło internetowe: https://en.oxforddictionaries.com/definition/general_manager [dostęp: 14.12.2017].

${ }^{61}$ Ł. Sztern, Wspótpraca nauki z biznesem. Formy i narzędzia wspierania, [w:] Wspótpraca nauki i biznesu. Doświadczenia i dobre praktyki wybranych projektów w ramach Programu Operacyjnego Innowacyjna Gospodarka na lata 2007-2013, red. K. Bromski, Warszawa 2013, s. 27-28.

${ }_{62}$ T. Pniewski, Kalisz z oddali, Kalisz 1988, s. 60. 
klimat towarzyskości naukowej charakterystycznej tylko i wyłącznie dla uniwersytetu.

- Jakościowiec. Nauczyciel akademicki to także dbający nie tylko o jakość swoich zajęć (nie ma nadgodzin), ale przede wszystkim o jakość swych naukowych publikacji. W swej pracy nie poddaje się „punktozie" ${ }^{63}$, ale odpowiedzialnie realizuje misję jaką jest jego praca.

- Księgowy. Ta rola pojawiła się w momencie wzrostu znaczenia różnego rodzaju projektów badawczych, finansowanych z rządowych i unijnych źródeł. Umiejętność pisania kosztorysów, preliminarzy oraz znajomość kosztów pośrednich, bezpośrednich, kwalifikowalnych, niekwalifikowalnych, narzutów i marży staje się wiedzą bezcenną.

- Kilkuetatowiec (Wieloetatowiec) zjawisko wieloetatowości jest popularne wśród akademików prawie tak samo, jak wśród medyków, o ile nie bardziej. Podjęcie zatrudnienia na drugim etacie bardzo często wymaga zgody głównego pracodawcy, niemniej jednak nauczyciele akademiccy bardzo często w ramach umów zleceń współpracują z innymi uczelniami, bardzo często prywatnymi. Od 2010 roku pracownicy akademiccy mają obowiązek informować, który etat jest ich podstawowym miejscem zatrudnienia ${ }^{64}$. W sytuacji większej liczby pracodawców zakres obowiązków ulega podwojeniu lub odpowiedniemu zwielokrotnieniu. Powodów wchodzenia w rolę kilku(wielo) etatowca jest według Renaty Siemieńskiej co najmniej kilka ${ }^{65}$. Po pierwsze, podstawowe wynagrodzenie jest za niskie w porównaniu z rynkowym, po drugie - trudno pozyskać środki na badania, po trzecie - brakuje możliwości angażowania się w badania, a pomoc i wsparcie ze strony uczelni w pisaniu wniosków jest niewystarczająca.

- Lider, Kierownik (projektu, szef zespołu badawczego). Ta rola stanowi ogromne wyzwanie, zwłaszcza dla młodego naukowca. Zarządzanie zespołem badawczym jest bardzo skomplikowane ${ }^{66}$, dotyczy to długich okresów (współ)pracy, interdyscyplinarności prowadzonych badań, problemów w dostępie do zasobów. Ważna jest $\mathrm{w}$ tej roli samodzielność i związane z nim doświadczenie, bowiem zadania kierownika mają charakter przede wszystkim naukowy, ale także organizacyjno-menadżersko-edukacyjny. Jak wskazuje Kathy Barker, do obowiązków kierownika między innymi należy: prowadze-

${ }^{63}$ E. Kulczycki, Punktoza jako strategia w grze parametrycznej w Polsce, Nauka i Szkolnictwo Wyższe, 2017, 1(49), s. 67.

${ }^{64}$ K. Cyran, B. Przywara, Społeczno-ekonomiczne uwarunkowania kariery naukowej w Polsce, [w]: Kariera naukowa w Polsce warunki prawne, społeczne i ekonomiczne, red. A. Waltoś, A. Rozmus, Warszawa 2012, s. 180.

${ }^{65}$ R. Siemieńska, Wprowadzenie. O doświadczeniach polskiej nauki i kształcenia. Problemy, które starano się rozwiązać bądź uchodzity uwadze, [w:] Uniwersytety, naukowcy i studenci, s. 8-11.

${ }^{66}$ M. Łazarowicz-Kowalik, Młody naukowiec w roli szefa zespołu badawczego, [w]: Tamże, s. 216-218. 
nie badań, motywowanie zespołu i organizowanie jego pracy, pozyskiwanie środków na badania, promocja osiągnięć, obowiązki administracyjne i sprawozdawcze, korygowanie, rekrutacja i monitoring ${ }^{67}$.

- Ławnik (Oceniający). W tej roli akademik występuje co najmniej dwa razy w ciągu trwania roku akademickiego. Ocenianie wiedzy studentów to bardzo trudna sztuka. To także sztuka wyboru formy sprawdzającej tę wiedzę, na przykład za pomocą testu, pracy pisemnej, a może odpowiedzi ustnej. Sposób i forma oceny mogą też wskazywać poziom zaangażowania akademika w jego pracę $^{68}$ (szybka i krótka forma wynika najczęściej z braku czasu). Przyjmuje się powszechnie, że nie ma ocen sprawiedliwych, bo wiedzę bardzo trudno zweryfikować kilkoma pytaniami. Ocena nie dotyczy tylko studentów. Samodzielni pracownicy nauki oceniają także innych pracowników badaczy-dydaktyków, będą recenzentami, członkami rad wydziałów, komisji dyscyplinarnych, komisji ds. stopni i tytułów oraz innych zespołów oceniających.

- Mistrz (Mentor) „(...) nauczyciel o wyrazistym charakterze, ogromnej wiedzy, ale z zainteresowaniami daleko wykraczającymi poza krąg spraw dotyczących nauczanego przedmiotu (...) indywidualność, kompetencja, osobowość, niepowtarzalność sposobu myślenia, dystans wobec siebie i pochlebców" $^{\prime \prime 9}$. Zaraża studentów swoją pomysłowością i oryginalnością myślenia. Nauczyciel akademicki w roli mentora nie oczekuje „wykucia” materiału. Jego celem nie jest sprawdzenie wiedzy, ale umiejętności myślenia ${ }^{70}$, wykorzystania zdobytej wiedzy w praktyce. Jedna z najbardziej trudnych, a zarazem pożądanych ról. Jest to konstrukt niełatwy do zdefiniowania i status trudny do uzyskania.

- Pracownik naukowo-dydaktyczny, co zostało niejednokrotnie podkreślone, z założenia musi dzielić swój czas pomiędzy badania i dydaktykę.

- Naukowiec (Badacz) i Nauczyciel. Jednym z podstawowych zadań jest tworzenie nowej wiedzy, która będzie stanowiła znaczący wkład w rozwój danej dyscypliny. Z kolei, obowiązek przekazania owej wiedzy spoczywa na nauczycielu. Henry Brook Adams powiedział, że „Nauczyciel ma wpływ na wieczność. Nie jest bowiem w stanie określić gdzie kończy się oddziaływanie" ${ }^{\prime 1}$. Działalność naukowca i nauczyciela łączy praca, która ma być wykorzystana nie tylko w wymiarze „tu i teraz”, ale w przyszłości, gdyż trud i wysiłek w nią włożony bywa odroczony w czasie. Świadkami i odbiorcami ich pracy są całe społeczeństwa oraz pojedyncze jednostki.

${ }^{67}$ Tamże, s. 218.

${ }_{68}$ P. Kaptur, Idealny nauczyciel, s. 71-72.

69 S. Rodziński, Relacja Mistrz-Uczeń. Anachronizm czy nowa szansa, [w:] W poszukiwaniu modelu dydaktyki akademickiej, red. D. Skulicz, Kraków 2004, s. 69.

${ }_{70}$ M. Kostera, A. Rosiak, Nauczyciel akademicki, Gdańsk 2008, s. 27-28.

${ }^{71}$ H.B. Adams, The Education of Henry Adams, rozdział 20, dokument elektroniczny, pobrano ze strony: http://www.gutenberg.org/files/2044/2044-h/2044-h.htm [1.12.2017]. 
- Opiekun. Ta rola związana jest bezpośrednio ze studentami. Akademik pełni nadzór merytoryczno-administracyjny nad studentami sprawując funkcję opiekuna roku, specjalności, koła naukowego, układając plany zajęć, sprawdzając i weryfikując obecności studentów na zajęciach celem wydania stosownych zaświadczeń dla instytucji zewnętrznych. Rozwiązuje bieżące problemy studentów, na przykład brak kontaktu z danym wykładowcą, niemożliwość podpięcia się pod przedmiot w systemie USOS, zbyt duża liczba nieobecności na przedmiocie itp.

- Przewodnik po świecie wiedzy ${ }^{72}$, ale także po rzeczywistości. Swoją wiedzę odnosi do aktualnych wydarzeń społecznych i politycznych. Wizualizuje i aktualizuje podręcznikowe terminy, często je podważając.

- Rekruter. Pomimo że czasy egzaminów wstępnych mamy już za sobą, pracownicy naukowo-dydaktyczni powoływani są na członków komisji rekrutacyjnych i w okresie wakacyjnym przyjmują dokumenty kandydatów na studentów.

- Sprawozdawca. To jedna z ról, która najdotkliwiej ujawnia się w pracy pracowników naukowo-dydaktycznych i zajmuje bardzo dużo czasu. Sprawozdania są indywidualne, zakładowe, dotyczą aktywności badawczej, jak i edukacyjnej. Oddawane w formie elektronicznej i tradycyjnej papierowej, kilkakrotnie bywają poprawiane i weryfikowane. Sprawozdania na stałe zagościły w życiu akademii i dotyczą wszystkich jej aspektów: spotkań, konferencji, seminariów, wyjazdów, zrealizowanych badań, zrealizowanych i niezrealizowanych zajęć oraz okolicznościowych eventów. Niestety, proces cyfryzacji niewiele w tej kwestii ułatwił.

- Sekretarka. Nauczyciel akademicki prowadzi osobisty sekretariat, pomimo że na uczelniach funkcjonują sekretariaty wspomagające pracowników naukowych w sprawach administracyjnych. Na potwierdzenie tej tezy wskazane zostaną wybrane zadania sekretariatu, do których między innymi należą: obsługa korespondencji przychodzącej i wychodzącej (poczty tradycyjnej i elektronicznej), gdyż liczba maili wpływająca na uniwersyteckie skrzynki indywidualne pracownicze i zakładowe jest liczona w dziesiątkach tygodniowo; segregowanie i przekazywanie korespondencji do adresatów na terenie firmy (uczelni); redagowanie pism, podań, próśb, opinii oraz drukowanie, kopiowanie, faksowanie i kompletowanie dokumentów; prowadzenie kalendarza spotkań, zaopatrywanie jednostki (w tym przypadku instytutu, zakładu, katedry, pracowni) w materiały biurowe, a czasami spożywcze (kawa, herbata, cukier i mleko).

${ }^{72}$ E. Tokarska, Nauczyciel akademicki jako przewodnik studenta w podróży po wiedzę, Forum Dydaktyczne, 2011, 7-8, s. 90. 
- Sędzia - Rozjemca. Zadanie to nie należy do najłatwiejszych, odnosi się do osądzania i sprawdzania oryginalności prac, wyłapywania plagiatów, ale również rozstrzygania sporów i konfliktów w grupach studenckich, które na poziomie akademickim nie są wcale rzadkością.

- Terapeuta. Jest to rola niezwykle trudna i odpowiedzialna. Niejednokrotnie nauczyciel akademicki bywa proszony o pomoc w sytuacjach kryzysowych dotykających studentów. Problemy te są natury osobistej i zawodowej, a pomoc $\mathrm{w}$ ich rozwiązaniu wymaga wyczucia sytuacji i empatii. Nauczyciele akademiccy często tworzą zespoły ds. interwencji kryzysowych, których przedmiotem działań są problemy natury emocjonalnej i psychicznej ${ }^{73}$. Chęć skorzystania z pomocy wykładowcy oznacza, że cieszy się on zaufaniem studentów.

- Uczeń - Student. Jednostka, zgodnie z ideą Lifelong Learning ${ }^{74}$, uczy się całe swoje życie, od urodzenia do późnej starości i nie tylko w szkole, ale także w pracy. Praca dydaktyka, naukowca wymusza bycie „na bieżąco". Studiowanie, poszukiwanie, analizowanie i monitorowanie badań oraz postępów w obszarze zainteresowań naukowych jest nieodłącznym elementem pracy nauczyciela. W związku z realizowaną profesją nauczyciel akademicki musi doskonalić swoje umiejętności i warsztat pracy, uczestniczyć w kursach, szkoleniach, realizować studia podyplomowe, uzyskiwać certyfikaty eksperckie. Wszystkie te zadania związane są z pełnieniem roli i wywiązywaniem się z obowiązków ucznia.

- Urzędnik (Formalista). Bardzo często w swojej aktywności ograniczony przepisami, regułami, drogą służbową wymagającą licznych zgód i podpisów lub wręcz przeciwnie - chowający się za przepisami niechętny do działania służbista, który swoim zachowaniem przyczynia się do utrzymania społecznego przekonania o skostniałości funkcjonalnej instytucji uniwersytetu i pracujących tam osób.

- Wychowawca. Wychowanie, obok kształcenia, stanowi najpoważniejszą część nauczycielskiej misji, sukcesywnie coraz istotniejszą w swojej ważności ${ }^{75}$. Niepodobne wydaje się, że funkcję taką pełni wykładowca akademicki w trakcie pracy z osobami dorosłymi, jednak w dobie upadku autorytetów nieoceniona staje się nauka współpracy, dobrych manier, podstawowych zasad savoir vivre'u oraz uwrażliwiania względem podstawowych wartości prawdy, dobra i piękna, ideałów, celów. Akademik-wychowawca kształtuje

${ }^{73}$ K. Nowakowska, Coraz więcej studentów z problemami psychicznymi, dokument elektroniczny, pobrano ze strony: http://serwisy.gazetaprawna.pl/edukacja/artykuly/929166,studia-depresja-studenci-zaburzenia-psychiczne.html [12.12.2017].

${ }^{74}$ Learning for Life: White Paper on Adult Education, Dublin 2000, s. 32.

75 J.M. Łukasik, K. Jagielska, R. Solecki, Nauczyciel. Wychowawca. Pedagog, Kielce 2013, s. 6. 
uczucia moralne i estetyczne, postawy społeczne i przekonania, wszechstronnie wpływa na osobowość wychowanków.

- Zbieracz (Archiwista, Kolekcjoner). Rola ta wynika z konieczności dokumentowania wszelkiej działalności dydaktycznej, naukowej i organizatorskiej, celem załączenia jej do wniosków o stypendia, do oceny pracowniczej, awansu zawodowego. Należy dołączyć do tego konieczność archiwizowania prac studentów (semestralnych, zaliczeniowych), list obecności oraz innej dokumentacji wytworzonej w trakcie procesu dydaktycznego. Analizując zakres wykonywanych obowiązków i zadań, którymi można by obdzielić kilka osób, pracownik dydaktyczno-naukowy jawi się jako pracownik hybrydowy wpisujący się w misję i koncepcję współczesnego uniwersytetu. Wyżej wymienione role mają wydźwięk zarówno pozytywy, jak i negatywny. Przedstawiają heterogeniczność środowiska akademickiego. Ich wstępny przegląd stanowi, bez wątpienia, przyczynek dla dalszej dyskusji i pogłębionych badań.

W natłoku obowiązków dydaktyczno-administracyjno-logistycznych, z których nauczyciel akademicki jest rozliczany, kwestie naukowe stają się sprawą drugorzędną, ze szkodą dla samych pracowników, stając się swoistego rodzaju epizodami. Termin "epizodysta naukowy” to nie kolokwializm, neologizm, to homonim. Epizodysta naukowy nie jest postacią jednolitą. Zaimplementować mu można wielorakie role, również te wymienione powyżej.

Według encyklopedycznej definicji synonimem epizodu jest fragment. Czy zatem wiedza epizodysty naukowego jest fragmentaryczna? Epizodysta naukowy to także dydaktyk uczący w kilku wyższych uczelniach, to wspomniany wieloetatowiec. Kiedy coraz częściej zatrudnia się nauczycieli akademickich w niepełnym wymiarze godzin, wymusza to na nich poszukiwanie dodatkowej pracy. W przypadku braku stabilizacji zatrudnienia, wszechobecnej na rynku pracy, dotyczącej również sfery szkolnictwa wyższego, podejmowanie dodatkowej pracy to konieczność, czasem wręcz przymus, a nie przywilej, czy świadomy wybór. Epizodysta naukowy zatrudniony w kilku uczelniach zdaje się prowadzić swoistego rodzaju uczelniany konwersatoryjno-wykładowy clubbing. Często potrafi w ciągu jednego semestru prowadzić kilkanaście przedmiotów z różnych naukowych dziedzin. W wyniku łańcuchowej reakcji liczne zajęcia dydaktyczne sprawiają, iż epizodysta nie znajduje już czasu na naukowe kwerendy biblioteczne, zagraniczne wyjazdy, granty, konferencje, co w konsekwencji prowadzi do braku publikacji. Bądź, kiedy się one pojawiają, mają charakter reminiscencyjny, powtarzalny, pozbawiony nowych tez czy doktryn. W tym przypadku epizodysta staje się uzurpatorem czyichś twierdzeń. Z kolei, brak zagranicznych wyjazdów sprawia, iż staje się naukowym autochtonem, patriotą lokalnej nauki, który nie aktualizuje swej wiedzy. 
Epizodysta naukowy nie będący pełnoetatowym pracownikiem, może stać się beneficjentem nadgodzin. Zgadzając się prowadzić przedmioty, z których ma wiedzę fragmentaryczną, staje się jej akwizytorem, a w skrajnych przypadkach dyletantem. Zajęcia prowadzi mechanicznie, niczym cyborg, z wykorzystaniem zbawiennych środków audiowizualnych. Strategiami przetrwania stają się dla niego filmy fabularne czy dokumentalne, prezentacje multimedialne bądź permanentna praca $w$ grupach i prowadzenie zajęć przez studentów. W skrajnych przypadkach epizodysta naukowy staje się kreatorem „szybkich zajęć" i każdy blok tematyczny traktuje niczym zajęcia organizacyjne. Tym samym, stosuje swoistego rodzaju recycling czasu, próbując pogodzić nadmiar dydaktycznych obowiązków. „Szybkie zajęcia” są dla epizodysty naukowego nie lada wyzwaniem, wymagają umiejętności skondensowania wiedzy, wybitnej zdolności organizacji czasu pracy i spełnienia oczekiwań studentów oraz pracodawcy. Epizodysta to także osoba pracująca aktywnie zawodowo poza uczelnią. Nie jest etatowym pracownikiem uczelni, co sprawia, że nie jest ograniczony prozą życia akademii, jej regulaminami, strukturami i schematyzmem. Bardzo często jest praktykiem prowadzącym specjalnościowy przedmiot. Abstrahuje od obowiązków stosowania sylabusów, treści, czy efektów kształcenia. Przekazuje wiedzę na konkretnych, realnych przykładach, czym wzbudza wśród studentów żywe zainteresowanie prowadzonym przedmiotem. Często bywa dotknięty ostracyzmem ze strony środowiska naukowego. Może zdarzyć się, iż naukowy epizodysta, pogrążony w defetyzmie, pauperyzacji własnych osiągnięć, kończy z reguły swą naukową karierę na poziomie doktoratu. Często, zmęczony oczekiwaniem na etat $\mathrm{w}$ wyższym szkolnictwie publicznym, obejmuje ważne funkcje $\mathrm{w}$ wyższym szkolnictwie prywatnym, stając się nierzadko kierownikiem czy nawet dziekanem jednostki naukowej, w której do tej pory "dorabiał".

Epizodysta naukowy stanowi określenie odnoszące się również do osób, u których w zawodowym résumé znajduje się pozycja związana z realizacją studiów doktoranckich. Oczywiście, nie każdy kto obroni rozprawę doktorską i uzyska stopień naukowy doktora zostaje na uczelni, jak też nie każdy kto pisze dysertację i realizuje badania chce zostać na uczelni. Przykład stanowią doktoraty wdrożeniowe ${ }^{76}$, które służą rozwiązaniu konkretnego problemu. W obu przypadkach doświadczenie uprawiania nauki jako aktywności zawodowej jest krótkie, realizowane w czasie pisania rozprawy doktorskiej, a w kontekście całożyciowej aktywności zawodowej - epizodyczne.

Naukowy epizodysta jest dobrym organizatorem umiejącym efektywnie zarządzać czasem, w myśl zasady: „im więcej obowiązków, tym więcej zrealizowanych celów". To często postać tragiczna, aktor drugoplanowy, którego

\footnotetext{
${ }^{76}$ Źródło internetowe: http://www.nauka.gov.pl/doktoraty-wdrozeniowe [15.12.2017].
} 
science dream nie spełnił się. To wybitny strateg, który w mistrzowski sposób porusza się $\mathrm{w}$ tej nie zdefiniowanej przestrzeni między dydaktyką a nauką, pełnej sprzeczności, niuansów, wyzwań, sukcesów i porażek, możliwości. Przestrzeń ta jest amorficzna, bez jasno określonych granic i struktur, przez co jeszcze trudniejsza do przejścia.

\section{Podsumowanie}

Praca nauczyciela akademickiego, dydaktyka, naukowca jest pracą twórczą, czasochłonną i odpowiedzialną. Jak każda profesja łączy w sobie wady i zalety, jednakże po dogłębnej analizie i przedstawionych argumentach można stwierdzić, że łączy w sobie wiele sprzecznych elementów. Przywołując opisane powyżej role i zadania, jakie nauczyciel akademicki, pracownik dydaktyczno-naukowy realizuje, odnosi się wrażenie, że kwestia nauki, prowadzenia badań i analiz ma charakter epizodyczny. Stąd też kontrowersyjny tytuł wskazujący realny czy też zbliżony do prawdziwego wymiar aktywności naukowej. Jej nikły zakres przedstawiony w artykule w żaden sposób nie ma na celu umniejszenia znaczenia naukowego charakteru pracy akademików, natomiast ma podkreślić znaczenie i wielowymiarowość pracy nauczyciela akademickiego, a przede wszystkim szeroki zakres obowiązków administracyjno-logistyczno-nadzorczych, które ustawicznie rosną. Wskazuje też na umiejętne żonglowanie czasem i rozciąganie go do granic możliwości, realizując kilka czynności jednocześnie, na przykład wykonując niecierpiące zwłoki telefony w drodze na zajęcia (w drodze do ośrodków zamiejscowych można wykonać ich kilka), sprawdzając prace studentów jadąc pociągiem na konferencje, czy odpisując na maile w trakcie zajęć, kiedy studenci wykonują zadanie.

Odnosząc się do cytatu Lucy Maud Montgomery: „Nauczyciel to rodzaj niewolnika, który wiecznie nie ma czasu”, warto przytoczyć dla porównania myśl szwedzkiej pedagożki i pisarki Ellen Key, która u progu XX wieku w swym manifeście ruchu Nowego Wychowania postulowała:

Nauczyciele i nauczycielki mej wymarzonej szkoły mają krótki dzień roboczy, dużo wypoczynku, wysokie wynagrodzenie, możliwość dalszego kształcenia się i najwyżej dwudziestoletni czas służby ${ }^{77}$,

podkreślając tym samym wysiłek, jakim jest nauczanie, prestiż i doniosłość pełnionej roli. Pogląd E. Key i zawarta w nim idea nie jest efemerydem, a wręcz przeciwnie - powinna na stałe wpisać się w sposób myślenia o pracy akademików.

\footnotetext{
${ }^{77}$ E. Key, Stulecie dziecka, Warszawa 2005, s. 165.
} 


\section{BIBLIOGRAFIA}

Adams H.B., The Education of Henry Adams, rozdział 20, dostępna na http:/ / www.gutenberg.org/files/2044/2044-h/2044-h.htm [1.12.2017].

Alek-Kowalski T., Nauka. Wielkopolska. Uczeni. Szkice socjologiczne, Wydawnictwo PTPN, Poznań 2003.

Ambrozik W., Przyszczypkowski K. (red.), Uniwersytet. Społeczeństwo. Edukacja, Wydawnictwo Naukowe UAM, Poznań 2004.

Bańka A., Zawodoznawstwo, doradztwo zawodowe, pośrednictwo pracy. Psychologiczne metody i strategie pomocy bezrobotnym, Wydawnictwo PRINT-B, Poznań 2005.

Baszkiewicz J., Młodość uniwersytetu, Wydawnictwo Wiedza Powszechna, Warszawa 1963.

Bauman Z., Wyzwania dla edukacji w dobie ptynnej nowoczesności, [w]: Uniwersytety, naukowcy i studenci w zglobalizowanym świecie, red. R Siemieńska, Wydawnictwo Naukowe Scholar, Warszawa 2017.

Brzezińska A., Brzeziński J. (red.), Ewaluacja procesu kształcenia w szkole wyższej, Wydawnictwo Fundacji Humaniora, Poznań 2000.

Brzezińska A., Brzeziński J., Eliasz A. (red.), Ewaluacja a jakość kształcenia w szkole wyższej, Wydawnictwo SWPS Academica, Warszawa 2004.

Brzeziński J., Trwałe wartości uniwersytetu, Forum Oświatowe, 1997, 1-2.

Centrum Badania Opinii Społecznej, Komunikat z badań Prestiż zawodów, Warszawa 2013.

Cyran K., Przywara B., Społeczno-ekonomiczne uwarunkowania kariery naukowej w Polsce, [w]: Kariera naukowa w Polsce warunki prawne, społeczne i ekonomiczne, red. A. Waltoś, A. Rozmus, Wydawnictwo Naukowe Scholar, Warszawa 2012.

Cywińska M. (red.), Być nauczycielem. Kompetencje wspótczesnego nauczyciela, Wydawnictwo Naukowe WSPiA, Poznań 2013.

Dąbrowa-Szefler M., Jabłecka J., Szkolnictwo wyższe w Polsce. Raport dla OECD, Ministerstwo Nauki i Szkolnictwa Wyższego, Warszawa 2007.

Denek K., Edukacja. Dziś-jutro, Wydawnictwo ŁWSH, Leszno - Poznań - Żary 2006.

Denek K., Uniwersytet w perspektywie społeczeństwa wiedzy. Nauka i edukacja w uniwersytecie XXI wieku, Wydawnictwo Naukowe WSPiA, Poznań 2011.

Dyrtkowski K., Popek M., Uwagi o przedsiębiorczości uczelni w modelu uniwersytetu III generacji [w]: Uniwersytet trzeciej generacji. Stan i perspektywy rozwoju, red. D. Burawski, Europejskie Centrum Wspierania Przedsiębiorczości, Poznań 2013.

Gambarelli G., Wspinaczka po profesurę. Przewodnik satelitarny po karierze akademickiej - od upadków na kolana i ciosów w plecy do zaszczytów, Wydawnictwa Fachowe CedeWu.pl, Warszawa 2011.

Janus K., Stownik pedagogiki i psychologii. Zagadnienia, pojęcia, terminy, Wydawnictwo Buchmann, Warszawa 2011.

Kaptur P., Idealny nauczyciel akademicki - mit czy realizm? Forum Oświatowe, 2011, 1(44).

Key E., Stulecie dziecka, Wydawnictwo Akademickie Żak, Warszawa 2005.

Kostera M., Rosiak A., Nauczyciel akademicki, Gdańskie Wydawnictwo Psychologiczne, Gdańsk 2008.

Kostkiewicz J. (red.), Uniwersytet i wartości, Oficyna Wydawnicza Impuls, Kraków 2007.

Kościelniak C., Makowski J. (red.), Wolność. Równość. Uniwersytet, Instytut Obywatelski, Warszawa 2011.

Kot S., Historia wychowania. Od starożytnej Grecji do połowy XVIII wieku, Wydawnictwo Akademickie Żak, Warszawa 1996. 
Krajewski M., Dzieje wychowania $i$ doktryn pedagogicznych, Wydawnictwo Novum, Płock 2005.

Kulczycki E., Punktoza jako strategia w grze parametrycznej w Polsce, Nauka i Szkolnictwo Wyższe, 2017, 1(49).

Kupisiewicz Cz., Szkice z dziejów dydaktyki, Oficyna Wydawnicza Impuls, Kraków 2010.

Kupisiewicz Cz., Kupisiewicz M., Stownik pedagogiczny, Wydawnictwo Naukowe PWN, Warszawa 2009.

Learning for Life: White Paper on Adult Education, Dublin 2000.

Lisiecka K. (red.), Zapewnienie jakości kształcenia w szkole wyższej, Wydawnictwo Uczelniane Akademii Ekonomicznej im. Karola Adamieckiego w Katowicach, Katowice 2001.

Litak S., Historia wychowania. Do wielkiej rewolucji francuskiej, Wydawnictwo WAM, Kraków 2006.

Łazarowicz-Kowalik M., Młody naukowiec w roi szefa zespołu badawczego, [w]: Uniwersytety, naukowcy $i$ studenci w zglobalizowanym świecie, red. R. Siemieńska, Wydawnictwo Naukowe Scholar, Warszawa 2017.

Łukasik J.M., Jagielska K., Solecki R., Nauczyciel. Wychowawca. Pedagog, Wydawnictwo Jedność, Kielce 2013.

Malewski M., Czy koniec ery akademickich podręczników? Teraźniejszość - Człowiek - Edukacja, 2008, 4(44).

Markiewiczowa H., Wybrane zagadnienia z historii wychowania, Wydawnictwo APS, Warszawa 2001.

Melosik Z., Uniwersytet i społeczeństwo. Dyskursy wolności, wiedzy i władzy, Oficyna Wydawnicza Impuls, Kraków 2009.

Milerski B,. Śliwerski B. (red.), Pedagogika. Leksykon PWN, Wydawnictwo Naukowe PWN, Warszawa 2000.

Możdżeń S.I., Historia wychowania do 1975, Wydawnictwo Diecezjalne, Sandomierz 2006.

Nowakowska K., Coraz więcej studentów z problemami psychicznymi, http://serwisy.gazetaprawna.pl/edukacja/artykuly/929166,studia-depresja-studenci-zaburzenia-psychiczne.html [12.12.2017].

Okoń W., Nowy stownik pedagogiczny, Wydawnictwo Akademickie Żak, Warszawa 2007.

Orczyk A., Zarys historii szkolnictwa i myśli pedagogicznej, Wydawnictwo Akademickie Żak, Warszawa 2008.

Pilch T. (red.), Encyklopedia pedagogiczna XXI wieku, t. VI, Wydawnictwo Akademickie Żak, Warszawa 2007.

Piwowar A., Kariera na uczelni jako nauczyciel akademicki, 2010, publikacja internetowa: https:// www.careers.uni.wroc.pl/media/uploads/karieraakadem.pdf [20.12.2017].

Pniewski T., Kalisz z oddali, Towarzystwo Miłośników Kalisza, Kalisz 1988.

Rodziński S., Relacja Mistrz-Uczeń. Anachronizm czy nowa szansa, [w]:W poszukiwaniu modelu dydaktyki akademickiej, red. D. Skulicz, Wydawnictwo Uniwersytetu Jagiellońskiego, Kraków 2004.

Rozporządzenie Ministra Nauki i Szkolnictwa Wyższego z 1 września 2011 roku w sprawie kryteriów oceny osiągnięć osoby ubiegającej się o nadanie stopnia doktora habilitowanego (DzU nr 196, poz. 1165).

Rozporządzenie Ministra Pracy i Polityki Społecznej z 7 sierpnia 2014 w sprawie klasyfikacji zawodów i specjalności na potrzeby rynku pracy oraz zakresu jej stosowania, s. 72 (DzU z 2014, poz. 1145).

Sajdak A., Paradygmaty kształcenia studentów i wspierania rozwoju nauczycieli akademickich. Teoretyczne podstawy dydaktyki akademickiej, Oficyna Wydawnicza Impuls, Kraków 2013. 
Siemieńska R., Wprowadzenie. O doświadczeniach polskiej nauki i kształcenia. Problemy, które starano się rozwiązać bądź uchodzity uwadze, [w]: Uniwersytety, naukowcy i studenci w zglobalizowanym świecie, red. R. Siemieńska, Wydawnictwo Wolters Kluwer Polska, Warszawa 2017.

Stankiewicz R. (red.), Nauczyciel - opiekun - wychowawca. Tradycje - teraźniejszość - nowe wyzwania, Eruditus, Poznań - Zielona Góra 2002.

Suchodolski B. (red.), Pedagogika, Państwowe Wydawnictwo Naukowe, Warszawa 1985.

Sztern Ł., Wspótpraca nauki z biznesem. Formy i narzędzia wspierania, [w:] Wspótpraca nauki i biznesu. Doświadczenia i dobre praktyki wybranych projektów w ramach Programu Operacyjnego Innowacyjna Gospodarka na lata 2007-2013, red. K. Bromski, PARP, Warszawa 2013.

Sztumski W., Student-klient, Sprawy, 2013, 8/9, (182).

Tokarska E., Nauczyciel akademicki jako przewodnik studenta w podróży po wiedzę, Forum Dydaktyczne, 2011, 7-8.

Ustawa z 27 lipca 2005 roku Prawo o szkolnictwie wyższym, DzU z 2005, nr 164, poz. 1365 z późn. zm.

Wnuk-Lipińska E., Wójcicka M. (red.), Jakość w szkolnictwie wyższym. Przykład Polski, Wydawnictwo TEPIS, Warszawa 1995.

Woźnicki J., Uczelnie akademickie jako instytucje życia publicznego, Fundacja Rektorów Polskich, Warszawa 2007.

Wójcicka M. (red.), Jakość kształcenia w szkolnictwie wyższym. Stownik tematyczny, Centrum Badań Polityki Naukowej i Szkolnictwa Wyższego, Warszawa 2001.

Żłobicki W., Podmiotowość człowieka jako podstawa edukacji akademickiej, [w:] Problemy edukacji w szkole wyższej, red. A. Szerląg, Oficyna Wydawnicza Impuls, Kraków 2006.

\section{Netografia}

http:/ / www.nauka.gov.pl/doktoraty-wdrozeniowe [15.12.2017].

https://en.oxforddictionaries.com/definition/general_manager [14.12.2017].

https://www.oxfordlearnersdictionaries.com/definition/english/publish-or-perish [12.12.2017]. 